\title{
KOMPENSASI DAN KEPUASAN KERJA KARYAWAN BAGIAN SALES AND MARKETING INDUSTRI OTOMOTIF DI BANDUNG
}

\author{
Hani Gita Ayuningtias \\ Ferdinal Syahputra \\ Arif Partono Prasetio
}

Fakultas Ekonomi dan Bisnis, Universitas Telkom

Email: hanigita@gmail.com; Partono67@gmail.com

Submitted: May 13, 2017; Reviewed: May 13, 2017; Accepted: Jul 5, 2017

\begin{abstract}
The automotive industry face intense competition to win the customers' choice. In doing so, they need to have a powerful sales team to pursue their target. Individual with higher satisfaction in their job will certainly give better contribution to organization. One of the antecedent of job satisfaction is compensation. The aim of the study is to analyze the effect of employee perception on job satisfaction. We use 385 automotive sales department in Bandung as participant. Data was collected using 50 items questionnaire. The Regression analysis with SPSS used to measure the effect of compensation on job satisfaction. The study found the correlation between two variables is 0,614. The effect of compensation on job satisfaction is 0.377 . The result proved that compensation still become important factor to build employees' satisfaction.this is in line with the automotive companys' policy which always provide bonuses for those who achieve the target and perform. This policy will drive employees to maintain their performance. Then, the positive cycle of rewards, satisfaction, and performance will keep on going.
\end{abstract}

Keywords: Job satisfaction, Compensation, Automotive Industry

\section{PENDAHULUAN}

Industri otomotif di Indonesia menjadi sebuah pilar yang penting dalam sektor manufaktur negara karena banyak perusahaan mobil yang terkenal di dunia membuka pabrik-pabrik manufaktur atau meningkatkan kapasitas produksinya. Saat ini industri otomotif tampil sebagai salah satu sektor andalan dalam kebijakan industri nasional yang memiliki peran besar terhadap produk domestik bruto (PDB) Indonesia (Gaikindo, 2017).

Industri otomotif di Indonesia telah banyak mengalami perkembangan baik untuk produk jadi ataupun rakitan. Di samping itu juga terdapat industri perakitan serta industri-industri pendukung lain seperti suku cadang, pengecatan, dan baterai. Kondisi ini semakin membuat pasar otomotif bergairah apalagi dengan adanya kebijakan baru pemerintah untuk memproduksi kendaraan hemat energi, harga terjangkau dan program pengembangan kendaraan bermotor dengan emisi rendah karbon dan ramah lingkungan (Gaikindo, 2016).

Perusahaan membutuhkan sumber daya manusia sebagai strategi baru untuk mencapai keunggulan dalam bersaing (Prasetioet al, 2017a). Salah satu unsur yang perlu diperhatikan perusahaan adalah kepuasan kerja karyawan. Kepuasan kerja merupakan perasaan dari seorang karyawan terhadap pekerjaannya. Karyawan yang merasa puas dengan pekerjaannya akan memiliki kinerja yang tinggi, begitu juga dengan karyawan yang merasa senang atas pekerjaannya akan meningkatkan produktivitas nya dalam bekerja (Lutfieet al, 2014).

Kepuasan kerja mempunyai peran penting terhadap pencapaian suatu organisasi atau perusahaan.Karyawan yang puas akan berupaya lebih baik lagi dengan segenap kemampuan yang dimiliki untuk menyelesaikan tugasnya. Hal ini selanjutnya akan menghasilkan kinerja dan pencapaian yang baik bagi organisasi 
atau perusahaan (Robbins \& Judge, 2013).Hal ini sejalan dengan konsep timbal balik atau pertukaran sosial (social exchange). Individu yang puas akan terus mengulang aktivitas yang membuat dia bisa mempertahankan kepuasannya. Perusahaan yang melihat kontribusi yang positif dari individu terkait akan kembali memberikan penghargaan atau kebijakan lain yang dapat meningkatkan kepuasan karyawan. Konsep ini dikembangkan oleh Homans pada tahun 1958 yang mendefinisikan Teori Pertukaran Social sebagai bentuk pertukaran kegiatan, baik yang bersifat nyata maupun tidak, memiliki nilai manfaat atau kerugian yang relatif antara dua pihak atau lebih (Cook \& Rice, 2006).

Kepuasan kerja adalah kunci untuk meningkatkan kinerja perusahaan dan kinerja individu karyawan. Karyawan dengan tingkat kepuasan kerja yang tinggi akan lebih termotivasi untuk mencapai tujuan perusahaan (Adeoye \&Fields, 2014).Terdapat faktor-faktor yang mempengaruhi tinggi atau rendahnya kepuasan kerja dalam perusahaan. Darko dan Amanor (2016) mendefinisikan ada lima faktor utama yang mempengaruhi kepuasan kerja yaitu pengakuan dan penghargaan, keamanan kerja, kompensasi, gaji dan opini. Kompensasi termasuk salah satu variabel yang mempengaruhi kepuasan kerja. Menurut penelitian yang dilakukan oleh Supatmi et.al (2013) menyatakan bahwa kompensasi berpengaruh positif terhadap kepuasan kerja karyawan.

Berdasarkan riset yang dilakukan oleh Qerja.com yang mengulas tingkat kepuasan karyawan pada industri yang ada di Indonesia dengan menggunakan lima factor; benefit, kesempatan karir, work life balance, nilai dan budaya serta manajemen perusahaan menunjukkan bahwa industry IT \&Telecomunication, Mining Oil \& Gas, FMCG (Fast Moving Consumer Goods), Banking \& Financial Services serta Insurance menduduki lima posisi teratas dalam hal kepuasan karyawan (Himawan, 2016).

Tabel 1 memperlihatkan temuan Triwijanarko (2016) terkait tingkat kepuasan karyawan otomotif terhadap gaji dan tunjangan selama semester I-2016, karyawan otomotif termasuk karyawan bagian sales dan marketing cukup puas dengan gaji dan tunjangan mereka meskipun tingkat kepuasan mereka tidak terlalu tinggi.
Tabel 1 Tingkat Kepuasan terhadap Kompensasi

\begin{tabular}{lc}
\hline \multicolumn{1}{c}{ Profesi } & $\begin{array}{c}\text { Tingkat kepuasan terhadap gaji dan } \\
\text { tunjangan }\end{array}$ \\
\hline Karyawan di perusahaan otomotif secara keseluruhan & 3,56 \\
Karyawan Sales di perusahaan otomotif & 3,6 \\
Karyawan Marketing diperusahaan otomotif & 3,46 \\
\hline
\end{tabular}

Dengan skala maksimal adalah 5, maka angka-angka di atas menunjukkan bahwa tingkat kepuasan akan kompensasi yang didapatkan berada pada tingkat yang relatif tinggi. Meski demikian, Triwijanarko (2016) juga menyajikan data terkait perbandingan gaji untuk industri otomotif secara umum untuk level manajer dan staf. Tabel 2 memperlihatkan rentang gaji tersebut. Nampak pada tabel tersebut bahwa posisi Marketing masih berada di bawah rata-rata industri otomotif. Tidak mengherankan apabila pada Tabel 1, karyawan pada posisi ini memiliki kepuasan yang relatif lebih rendah.

Tabel 2 Rata - Rata Gaji Staf dan Manajer di Industri Otomotif Tahun 2016

\begin{tabular}{lll}
\hline \multicolumn{1}{c}{ Profesi } & \multicolumn{1}{c}{ Level } & Rata-rata Gaji \\
\hline Karyawan di perusahaan otomotif secara keseluruhan & Staf & Rp. 4.291 .000 \\
& Manajer & Rp. 7.015 .000 \\
Karyawan Sales di perusahaan otomotif & Staf & Rp. 3.835 .800 \\
& Manajer & Rp. 7.217.500 \\
Karyawan Marketing di perusahaan otomotif & Staf & Rp. 4.168.000 \\
& Manajer & Rp. 6.741.500 \\
\hline
\end{tabular}

Berdasarkan penelitian pendahuluan yang dilakukan, diketahui bahwa tingkat kepuasan karyawan pada bagian otomotif berada pada tingkat relatif tinggi. Kondisi ini dapat dikatakan sejalan dengan apa yang disajikan pada gambaran kepuasan terhadap kompensasi. Berdasarkan fenomena tersebut, penelitian ini dilakukan untuk mengetahui serta menjelaskan bagaimana pengaruh kompensasi terhadap kepuasan kerja di industri otomotif Bandung. Hasil penelitian ini diharapkan dapat menambah keluasan kajian mengenai kepuasan kerja dan kompensasi.

\section{KAJIAN LITERATUR dan HIPOTESIS}

Penelitian ini berlatar belakag keilmuan sumberdaya manusia dan perilaku organisasi. Variabel independen, kompensasi, merupakan bagian dari kajian manajemen sumberdaya manusia. Sumberdaya manusia merupakan ilmu yang mempelajari hal-hal terkait pengelolaan tenaga kerja yang mencakup; perencanaan, pengaturan, mengarahkan, pengadaan dan pengembangan, kompensasi, dan hubungan antar 
organisasi dan karyawan (Hasibuan, 2014; Sunyoto, 2012; Gaol, 2014). Pengelolaan sumberdaya manusia yang efektif diharapkan dapat memudahkan pencapaian tujuan organisasi, karyawan, dan lingkungan.

Sedangkan perilaku organisasi merupakan ilmu yang mempelajari pola interaksi antara individu dan kelompok dalam suatu organisasi. Perkembangan konsep perilaku didasarkan pandangan pentingnya suatu organisasi untuk mengelola interaksi antara sumberdaya manusia atau karyawan. Pengelolaan kemampuan ini, baik dalam istilah peran interpersonal, ketrampilan berhubungan dengan manusia, komunikasi dan aktivitas networking, maupun fungsi kepemimpinan, semuanya bermuara pada bagaimana atasan atau manajer mengembangkan kemampuan mereka dalam berinteraksi dengan karyawan secara efektif (Robbins \& Judge, 2013). Perilaku organisasi mempelajari interaksi antar individu dan kelompok dalam organisasi Serta bagaimana perilaku mereka mempengaruhi kinerja organisasi. Beberapa kajian di dalam perilaku organisasi adalah; motivasi, turnover, komitmen, produktivitas, perilaku atasan, penggunaan kekuasaan, kepuasan kerja, dan komunikasi (Robbins \& Judge, 2013).

Kompensasi sebagai salah satu bentuk penghargaan (reward) yang harus dirancang secara komprehensif dengan bentuk lain sehingga dapat menjadi mekanisme penghargaan yang dapat membuat karyawan merasakan kepuasan dalam pekerjaannya (Armstrong, 2009). Pengertian kompensasi mencakup balas jasa atau imbalan yang diberikan oleh perusahaan kepada karyawan karena telah berkontribusi terhadap pencapaian perusahaan (Hartatik, 2014; Marwansyah, 2013).Rivai \& Sagala (2013) mengemukakan bahwa pemberian kompensasi merupakan salah satu fungsi manajemen sumberdaya manusia yang terkait dengan pemberian penghargaan. Selanjutnya, Kaswan (2012) mengatakan tujuan pemberian kompensasi adalah untuk meningkatkan kepuasan kerja karyawan, pengadaan karyawan yang efektif, memotivasi karyawan, meningkatkan disiplin kerja karyawan, menghindari pengaruh dari serikat buruh dengan kompensasi yang baik, mendukung pencapaian strategi dan sasaran jangka pendek organisasi.

Kepuasan kerja merupakan sikap kerja yang perlu dibangun oleh organisasi. Kepuasan kerja diyakini dapat meningkatkan kinerja karyawan (Robbins \& Judge, 2013). Pengertian kepuasan kerja meliputi perasaan dan sikap emosional dari karyawan terhadap kegiatan yang dilakukan dalam suatu organisasi (Hasibuan, 2014; Sunyoto, 2012; Yusuf dan Al Arif, 2015). Hasibuan(2014) menyatakan bahwa kepuasan kerja karyawan merupakan kunci pendorong moral, kedisplinan dan prestasi kerja karyawan dalam mendukung terwujudnya tujuan perusahaan. Di samping mempengaruhi kinerja karyawan, kepuasan kerja juga dapat meningkatkan komitmen organisasi (Prasetioet $a l, 2017 b$ ), menurunnya keinginan untuk keluar (Gibson et al, 2012), kepuasan pelanggan (Schermerhorn et al, 2012), perilaku kewarganegaraan organisasi-OCB (George \& Jones, 2012).

\section{Hubungan Kompensasi dan Kepuasan Kerja}

Terdapat faktor-faktor yang mempengaruhi tinggi rendahnya kepuasan kerja di dalam suatu perusahaan atau organisasi. Kompensasi termasuk ke dalam salah satu faktor yang mempengaruhi kepuasan kerja. Hal ini dikuatkan oleh penelitian terdahulu. Penelitian di Nigeria oleh oleh Adeoye dan Fields(2014) menemukan hubungan positif antara kompensasi dan kepuasan kerja. Penelitian lain yang sependapat dengan Adeoye dan Fields bahwa kompensasi memiliki pengaruh yang positif dan signifikan terhadap kepuasan kerja adalah Muguongo(2015) di Kenya, Nazir et.al(2014) di Inggris, Dhermawan et.al(2012) di Bali, dan Supatmi et.al(2013) di Malang. Kompensasi yang baik diyakini dapat meningkatkan kinerja karyawan. Berdasarkan hasil yang dikemukakan oleh penelitian terdahulu tersebut ditetapkan hipotesis untuk penelitian ini adalah;

$\mathbf{H}_{\mathbf{1}}-$ Kompensasi berpengaruh signifikan positif terhadap kepuasan kerja.

\section{METODOLOGI}

\section{Responden dan Prosedur}

Penelitian ini dilakukan antara bulan Februari hingga Desember 2016 dengan menggunakan 385 responden. Responden diambil dari karyawan di bagian pemasaran dan penjualan di lima pusat penjualan kendaraan roda empat di Bandung. Metode sampling yang digunakan adalah metode sampling non-probabilitas dengan pendekatan convience. Penyebaran kuesioner dilakukan secara langsung di masing-masing pusat penjualan. Responden tidak dipilih secara acak. Distribusi kuesioner dilakukan oleh bagian customer relationship coordiantor. 


\section{Alat Ukur}

Kuesioner yang digunakan memiliki 50 item pertanyaan; 32 item untuk mengidentifikasi persepsi terhadap kompensasi dan 18 untuk kepuasan kerja. Responden diminta memilih satu dari lima alternatif jawaban yang paling sesuai. Kelima alternatif jawaban tersebut dibuat berdasarkan skala Likert dengan alternatif pilihan dari 1 (sangat tidak setuju), 2 (tidak setuju), 3(antara setuju dan tidak setuju), 4 (setuju), dan 5 (sangat setuju).

32 item untuk kompensasi dikembangkan berdasarkan konsep Rivai \& Sagala (2013) yang menetapkan lima dimensi kompensasi; Gaji, upah, insentif, tunjangan, dan asuransi. Salah satu contoh pertanyaan yang diajukan adalah 'Upah yang diberikan oleh perusahaan dapat memenuhi kebutuhan saya'. Tingkat reliabilitas untuk item-item pengukuran kompensasi adalah $\alpha=$.932. Kepuasan kerja diukur menggunakan 18 item yang dikebangkan berdasarkan konsep dua dimensi; intrinsik dan ekstrinsik dari Kaswan (2012). Cronbach's Alpha untuk relibilitasnya mencapai .856. setelah dilakukan uji validitas, ditemukan dua buah item yang tidak valid sehingga tidak digunakan. Dengan demikian jumlah item yang digunakan untuk mengukur kepuasan kerja adalah 16. Salah satu contoh item adalah 'Saya memiliki rasa tanggung jawab atas pekerjaan yang saya lakukan'.

\section{Analisis Data}

Pembahasan di dalam penelitian ini dilakukan menggunakan metode eksplanatori. Silalahi (2012) mengatakan bahwa penelitian eksplanatori bertujuan untuk menjelaskan hubungan antara dua atau lebih gejala atau variabel.Untuk mengukur hubungan dan pengaruh antar variabel digunakan analisis regresi sederhana dengan bantuan SPSS 21. Sebelum dilakukan analisis regresi data harus dipastikan memenuhi asumsi klasik (uji normalitas dan heterokedastisitas). Data pada penelitian ini telah memenuhi uji normalitas karena nilai syg. dengan uji KolmogorovSmirnov di atas 0,05. Demikian juga dalam data ini tidak ditemukan adanya masalah heterokedastisitas karena nilai syg. dengan uji Glejser di atas 0,05.

\section{PEMBAHASAN DAN HASIL}

\section{Profil Responden}

Tabel 3 memperlihatkan profil responden yang digunakan di dalam penelitian ini. nampak pada tabel bahwa responden pria lebih banyak terwakili (58\%). Kondisi ini relatif normal untuk pekerjaan pemasaran dan penjualan yang biasanya memerlukan ketahanan untuk bekerja di lapangan. Hal yang cukup mengherankan adalah banyaknya lulusan S1 yang bekerja pada bagian ini (49\%) diikuti oleh Diploma (40\%). Hal ini menandakan bahwa kebutuhan akan lulusan SMA saat ini sudah semakin berkurang. Lulusan diploma dan S1 lebih diprioritaskan karena tingkat upah yang relatif sama akan tetapi perusahaan memiliki kompetensi lebih tinggi. Tidak ada karyawan yang berada pada kelompok usia di atas 46. Pekerjaan pemasaran dan penjualan memang biasanya dilakukan oleh kelompok usia yang lebih muda. Persentase pada rentang usia di atas $24-35$ tahun memang sesuai jika mendominasi responden.

Tabel 3 Profil Responden

\begin{tabular}{|c|c|c|c|}
\hline \multirow[b]{2}{*}{ Faktor Demografis } & \multicolumn{3}{|c|}{ Jumlah } \\
\hline & Keterangan & Responden & Presentase \\
\hline \multirow{2}{*}{ Jenis Kelamin } & Pria & 223 & $58 \%$ \\
\hline & Wanita & 162 & $42 \%$ \\
\hline \multirow[t]{4}{*}{ Usia } & $<24$ & 107 & $28 \%$ \\
\hline & $>24-35$ & 185 & $48 \%$ \\
\hline & $>35-46$ & 93 & $24 \%$ \\
\hline & $>46$ & 0 & $0 \%$ \\
\hline \multirow[t]{4}{*}{ Pendidikan } & SMA & 35 & $9 \%$ \\
\hline & Diploma & 154 & $40 \%$ \\
\hline & S1 & 190 & $49 \%$ \\
\hline & S2 & 6 & $2 \%$ \\
\hline \multirow[t]{2}{*}{ Status } & Belum Menikah & 182 & $47 \%$ \\
\hline & Menikah & 203 & $53 \%$ \\
\hline \multirow[t]{4}{*}{ Lama Bekerja } & $<5$ tahun & 212 & $55 \%$ \\
\hline & $>5-10$ tahun & 173 & $45 \%$ \\
\hline & $>10-15$ tahun & 0 & $0 \%$ \\
\hline & $>15$ tahun & 0 & $0 \%$ \\
\hline \multirow[t]{8}{*}{ Gaji } & $<1.500 .000$ & 0 & $0 \%$ \\
\hline & $>1.500 .000-$ & & \\
\hline & 2.500 .000 & 28 & $7 \%$ \\
\hline & $>2.500 .001-$ & & \\
\hline & 3.500 .000 & 71 & $18 \%$ \\
\hline & $>3.500 .001-$ & & \\
\hline & 4.500 .000 & 95 & $25 \%$ \\
\hline & $>4.500 .000$ & 191 & $50 \%$ \\
\hline
\end{tabular}

53\% dari responden (203 orang) sudah menikah menandakan bahwa karyawan pada bagian ini memiliki tanggung jawab yang lebih besar dengan adanya keluarga (istri dan anak). Masa kerja responden relatif terbagi rata antara kelompok di bawah 5 tahun dan di atas 5 hingga 10 tahun. Meski tidak ada responden yang memiliki masa kerja di atas 10 tahun, akan tetapi data ini memperlihatkan bahwa karyawan pada bagian ini juga relatif tinggal lebih lama pada pekerjaan tersebut. Hal ini dapat menjadi indikasi bahwa mereka menikmati kegiatan yang dilakukan. Kondisi yang lebih mengejutkan adalah pada informasi terkait gaji. 50\% dari responden menyatakan mendapatkan penghasilan 
di atas Rp. 4.500.00,-. Pekerjaan di bagian pemasaran dan penjualan memang memerlukan upaya yang lebih dibandingkan pekerjaan di belakang meja. Akan tetapi bagi individu yang berprestasi dan mau berusaha lebih biasanya mereka akan bisa mendapatkan penghasilan lebih besar. Untuk Kota Bandung, pendapatan tadi sudah di atas upah regional sebesar Rp. 2.460.000,-.

Persepsi karyawan atas kompensasi yang saat ini diterima berada pada kategori sangat tinggi (rata-rata 3,39). Demikian juga dengan persepsi terkait kepuasan kerja (3.51). Apabila dikaitkan dengan data demografi di atas, kondisi tersebut dapat dimaklumi. Tingkat gaji yang sudah cukup tinggi dan besarnya persentase karyawan yang sudah bekerja di atas 5 tahun dapat menjadi pertanda bahwa karyawan merasa senang dengan pendapatannya saat ini dan merasa puas menjalankan pekerjaannya.

\section{Analisis Regresi Sederhana}

Analisis regresi dilakukan menggunakan SPSS 21. Tabel 4 memperlihatkan hasil regresi secara lengkap.

Tabel 4 Hasil Regresi Linier

\begin{tabular}{|c|c|c|c|c|c|c|}
\hline \multicolumn{2}{|c|}{ Model } & $\mathrm{R}$ & $\begin{array}{c}\mathrm{R} \\
\text { Square }\end{array}$ & $\begin{array}{c}\text { Adjusted } \\
\text { R } \\
\text { Square }\end{array}$ & \multicolumn{2}{|c|}{$\begin{array}{l}\text { Std. Error of the } \\
\text { Estimate }\end{array}$} \\
\hline & & ,599a & ,359 & ,357 & \multicolumn{2}{|c|}{,21053 } \\
\hline \multirow[t]{2}{*}{ Model } & & Sum of & & Mean & & \\
\hline & & Square & $\mathrm{df}$ & Square & $\mathrm{F}$ & Sig. \\
\hline \multirow[t]{3}{*}{1} & Regression & 9,513 & 1 & 9,513 & 214,629 &, $000 \mathrm{~b}$ \\
\hline & Residual & 16,976 & 383 & ,044 & & \\
\hline & Total & 26,489 & 384 & & & \\
\hline
\end{tabular}

Tabel 2 memperlihatkan bahwa kompensasi memiliki pengaruh signifikan positif terhadap kepuasan kerja $(p<0.05)$. Korelasi di antara keduanya juga berada pada kategori cukup kuat (0.599). tabel di atas juga memperlihatkan besarnya pengaruh kompensasi terhadap kepuasan kerja sebesar $35.9 \%$. Hasil analisis regresi tersebut menjawab hipotesis penelitian ini bahwa terdapat pengaruh signifikan dan positif dari variabel kompensasi terhadap kepuasan kerja. Hasil ini sesuai dengan penelitian sebelumnya dari Devi \& Sudibia (2015) di Bali, Adeoye dan Fields(2014) di Afrika Selatan, Muguongo(2015) di Kenya, Nazir et.al(2014) di Inggris, Dhermawan et.al(2012) di Bali, Supatmi et.al(2013) di Malang, Lauren (2017) di Jakarta, Potale et al (2015) di Manado, dan Prasastono (2012) di Semarang. Latar belakang budaya lokal di Indonesia dan budaya dari negara lain ternyata tidak membuat perbedaan hasil terkait pengaruh kompensasi terhadap kepuasan kerja.

Program atau kebijakan kompensasi yang dipersepsikan positif oleh karyawan akan meningkatkan kepuasan kerja mereka. dengan demikian, perusahaan diharapkan bisa mengelola paket kompensasi yang lebih menarik untuk mempertahankan tingkat kepuasan kerja karyawan. Hal ini perlu dilakukan karena karyawan yang puas memiliki kecenderungan untuk menjalankan pekerjaan lebih baik dan bekerja lebih baik pula. Dikaitkan dengan industri otomotif, paket kompensasi yang ditawarkan sebaiknya menyasar pada kebutuhan perusahaan untuk selalu memperbesar pasar dan juga kebutuhan karyawan untuk mendapatkan penghasilan yang lebih besar. Dengan demikian model kompensasi berbasis target masih bisa dipertahankan. Pencapaian penjualan, jumlah kunjungan konsumen, jumlah pelanggan tetap, dan banyaknya panggilan kepada calon konsumen dapat menjadi dasar penentuan kompensasi. Meski demikian, karena pada dasarnya manusia memiliki kebutuhan dasar, maka perusahaan sebaiknya juga menyiapkan kompensasi umum yang setidaknya dapat memenuhi kebutuhan dasar karyawan. Apabila seluruh komponen kompensasi dikaitkan dengan kinerja, pada kondisi tertentu karyawan sebaliknya akan merasa tidak puas. Ketika pasar sedang mengalami kelesuan dan konsumen cenderung tidak membelanjakan uangnya untuk kepentingan konsumtif, maka karyawan bagian pemasaran dan penjualan akan merasa tidak nyaman karena penghasilan mereka akan turun drastis.

\section{KESIMPULAN}

Penelitian ini mendukung temuan penelitian terdahulu bahwa kompensasi memiliki pengaruh signifikan dan positif terhadap kepuasan kerja. Dengan demikian hasil ini menguatkan pandangan tersebut. Paket kompensasi yang dipersepsi baik oleh karyawan dapat menjadi faktor pendorong bagi terbentuknya kepuasan kerja. Karyawan bagian sales dan marketing pada industri otomotif di Kota Bandung merasakan bahwa kompensasi yang mereka terima sudah sesuai dengan kebutuhan. Sehingga tidak mengherankan mereka merasakan tingkat kepuasan yang tinggi dalam pekerjaannya. Pada penelitian ini teridentifikasi pengaruh yang relatif besar $(35.9 \%)$. Hasil ini bisa menjadi 
acuan bagi penelitian selanjutnya yang menganalis hubungan antar variabel yang sama.

\section{DAFTAR PUSTAKA}

Adeoye, A.O \& Fields, Z. (2014). Compensation Management and Employee Job Satisfaction: A Case Of Nigeria. Journal Social Science. 41:3. 345-352.

Armstrong, M. (2009). Armstrong's Handbook of Human Resource Management Practice, 11th Edition. London: Kogan Page.

Cook, Karen S \& Rice, E. (2006). Social Exchange Theory.In DeLamater, John. The Handbook of Social Psychology.hlm. 5376. New York: Springer.

Darko, E.A. \& Amanor, M. (2016). Factors Affecting Job Satisfaction of Agricultural Sector Wokers in Ghana.American Journal of Business, Economics and Management. 4:4.89-93.

Devi, N.L.M.S., \& Sudibia, G.A. (2015). Pengaruh Job Insecurity, dan Kompensasi Finansial Terhadap Kepuasan Kerja danTurnover intention: (Studi Pada Karyawan Kontrak di Bali Dynasty Resort). E-Jurnal Manajemen Unud, Vol. 4, No. 4, hlm. 1047-1066.

Dhermawan, A.A.N.B., Sudibya, I.G.A., \& Utama, I.W.M. (2012). Pengaruh Motivasi, Lingkungan Kerja, Kompetensi dan Kompensasi terhadap Kepuasan Kerja dan Kinerja Pegawai di Lingkungan Kantor Dinas Pekerjaan Umum Provinsi Bali. Jurnal Manajemen, Strategi Bisnis dan Kewirausahaan. 6:2.173 -184

Gaikindo. (2016). Perkembangan Industri Otomotif. http://www.gaikindo.or.id/ perkembangan/. Di akses April 2017.

Gaikindo. (2017). Industri Otomotif Sanggup Tingkatkan Kontribusi Ekonomi. http://www.gaikindo.or.id/industriotomotif-sanggup-tingkatkan-kontribusiekonomi/. Di akses April 2017.

Gaol, J. L. (2014). A to Z Human Capital Manajemen Sumber Daya Manusia. Jakarta: PT. Grasindo.

George, J.M. \& Jones, G.R. (2012). Understanding and Managing Organizational Behavior, 6th Edition. New Jersey: Prentice Hall.

Gibson, J.L., Ivancevich, J.M., Donnelly Jr., J.H., \& Konopaske, R. (2012). Organizations: Behavior, Structure, Processes, $14^{\text {th }}$ edition. New York: McGraw-Hill.
Hartatik, I.P. (2014). Buku Praktis Mengembangkan SDM. Jogjakarta: Laksana.

Hasibuan, M. (2014). Manajemen Sumber Daya Manusia. Edisi Revisi. Jakarta: PT Bumi Aksara.

Himawan, A. (2016). Karyawan Di 5 Industri Ini Punya Kepuasan Kerja Tertinggi. http://www.suara.com/bisnis/2016/07/28/0 93815/karyawan-di-5-industri-ini-punyakepuasan-kerja-tertinggi. Di akses Maret 2017.

Kaswan. (2012). Manajemen Sumber Daya Manusia Untuk Keunggulan Bersaing Organisasi. Yogyakarta: Graha Ilmu.

Lauren, J. (2017). Pengaruh Kompensasi Dan Komitmen Organisasional Terhadap Turnover Intention Dengan Kepuasaan Kerja Sebagai Variabel Mediasi Pada Karyawan PT. "X". Agora, Vol. 5, No. 1, 291-300.

Lutfi, H., Prasetio, A.P., \& Turipanam, D.A. (2014). The Effect of The Work-Family Conflict And Employee's Job Satisfaction Towards The Organization Commitment. Jurnal Siasat Bisnis. 30(2). 143-151.

Marwansyah. (2013). Manajemen Sumber Daya Manusia. Bandung: Alfabeta.

Muguongo, M.M.,Muguna, A.T., \& Muriithi, D.K. (2015). Effects Of Compensation On Job Satisfaction Among Secondary School Teachers In Maara Sub- County Of TharakaNithi County, Kenya. Journal Of Human Resources Management. 3:6. 4759.

Nazir, T., Khan, S.U.R., Shah, S.F.H. \& Zaman, K. (2014). Impact Of Reward And Compensation On Job Satisfaction: Public And Private Universities Of UK. MiddleEast Journal Of Scientific Research.14:3. 394-403.

Potale, R., \& Uhing, Y. (2015). Pengaruh Kompensasi dan Stres Kerja Terhadap Kepuasan Kerja Karyawan Pada PT. Bank Sulut Cabang Utama Manado. Jurnal EMBA, 63 Vol. 3 No.1 Maret 2015, 63-73.

Prasastono, N. (2012). Pengaruh Gaya Kepemimpinan Dan Kompensasi Terhadap Motivasi Kerja Karyawan Hotel Muria Semarang. Dinamika Kepariwisataan Vol. XI No. 2.

Prasetio, A.P., Yuniarsih, T., \& Ahman, E. (2017a). Job Satisfaction, Organizational Commitment, And Organizational Citizenship Behaviour In State-Owned 
Banking. Universal Journal Of Management. 5(1). 32-38.

Prasetio, A.P., Yuniarsih, T., Ahman, E., \& Sary, F.P. (2017b). Mediating Role of Job Satisfaction in the Relation of Work-Life Balance and Organizational Commitment. International Journal of Business and Management Invention, Vol. 6, Issue 2, 37-43.

Rivai, V. \& Sagala, E.J. 2013. Manajemen Sumber Daya Manusia untuk Perusahaan dari Teori ke Praktik. Jakarta: PT Raja Grafindo.

Robbins, S.P., \& Judge, T.A. (2013). Organizational Behavior, $15^{\text {th }}$ edition. New Jersey: Pearson Education Inc.

Schermerhorn, Jr. J. R., Osborn, R.N., Uhl-Bien, M., \& Hunt, J.G. (2012). Organizational Behavior, $12^{\text {th }}$ edition. New Jersey: John Wiley \& Sons.

Sunyoto, D. 2012. Manajemen Sumber Daya Manusia.Yogyakarta: CAPS.

Supatmi, M. E.,Nimran, U., \& Utami, H.N. (2013). PengaruhPelatihan, Kompensasi, Terhadap Kepuasan Kerja Karyawan dan Kinerja Karyawan. Jurnal Profit.7:1. 2537.

Triwijanarko, R. (2016). Berapa Gaji Karyawan Sales dan Marketing Perusahaan Otomotif diIndonesia?http://marketeers.com/berapagaji-karyawan-sales-dan-marketingperusahaan-otomotif-di-indonesia/. $\quad \mathrm{Di}$ akses Maret 2017.

Yusuf, B. \& Al Arif, N.R. (2015). Manajemen Sumber Daya Manusia Di Lembaga Keuangan Syariah. Jakarta: PT. RajaGrafindo Persada. 
Jurnal Manajemen Maranatha — Vol. 17 Nomor 1, November (2017) 